\title{
Effects of power lines on flight behaviour of the West-Pannonian Great Bustard Otis tarda population
}

\author{
RAINER RAAB, PÉTER SPAKOVSZKY, EIKE JULIUS, CLAUDIA SCHÜTZ \\ and CHRISTIAN H. SCHULZE
}

\section{Summary}

Flight directions of Great Bustards Otis tarda after take-off were used to analyse effects of power lines on spatial movements of this highly endangered bird species. Data on flight directions came from Great Bustard observations conducted in eastern Austria (northern and eastern parts of Lower Austria, northern part of Burgenland), western Slovakia and western Hungary. Flight directions were determined by a constructed line connecting take-off site and the bird's position after a flown distance of $100 \mathrm{~m}$. Up to a distance of $800 \mathrm{~m}$ from the nearest power line, mean flight direction of Great Bustards after take-off deviated significantly from a random distribution. The mean flight direction angles clearly indicate that take-off flight routes point away from power lines at an angle of approximately $180^{\circ}$. Furthermore, flight directions of bustards still deviated from a random distribution in two 200-m distance bands much further away from

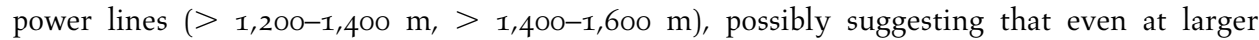
distances from power lines flight directions might still be affected by such artificial linear landscape structures. With increasing distance to nearest power lines, mean vector length $r$ values of flight paths decrease significantly, while circular standard deviations $S$ values increase significantly. Very similar results were achieved independently if all data were pooled or analysed separately for individual study areas for which the number of flight observations was large enough to conduct reliable analyses. Our study reports a strong effect of power lines on the flight behaviour of Great Bustards, at least up to a distance of $800 \mathrm{~m}$, perhaps even up to $1,600 \mathrm{~m}$. Although this may significantly reduce the risk of collision with power lines it most likely has severe consequences for the spatial movements of birds within the entire landscape and between potentially suitable breeding and foraging habitats.

\section{Introduction}

Spatial movements of highly mobile vertebrates such as birds are affected by natural and artificial landscape structures or direct anthropogenic disturbance (Burger 1998, Drewitt and Langston 2008). Artificial structures - such as wind farms or power lines - can affect flight behaviour or, in severe cases, increase bird mortality due to deadly collisions (wind turbines: Osborn et al. 1998, PNAWPPM-III 2000; power lines: Bevanger 1995, Bevanger and Brøseth 2004, Drewitt and Langston 2008, Jenkins et al. in press, Rollan et al. in press). Wind turbines can have a particularly strong effect on migrating birds when bad weather conditions induce them to fly low, or during take-off and landing. Collision risk for migrating birds flying low just after take-off and just before landing could be reduced by not placing tall structures near locations where 
migratory birds concentrate before or during migration (Hanowski and Hawrot 2000). However, migratory birds conducting daily flights from overnight roosts to feeding areas appear to be at a particularly high risk (Hanowski and Hawrot 2000), a situation which should also apply to resident birds.

Although mortality caused by collision with wind turbines can be higher than that caused by any other human-made structures (Barrios and Rodríguez 2004), power lines can also have severe effects (Nelson and Curry 1995, Osborn et al. 1998). For example, the annual losses of Western Capercaillie Tetrao urogallus, Black Grouse Tetrao tetrix and Willow Grouse Lagopus lagopus due to collisions with high voltage power lines in Norway were estimated at 20,000, 26,000 and 50,000 birds, respectively, representing about $90 \%, 47 \%$ and $9 \%$ of the annual hunting harvest of these species (Bevanger 1995).

Concerning wind farms, bird mortalities have not been found to be associated with either structural attributes or visibility of these artificial structures (Barrios and Rodríguez 2004). The collision risk of birds with power lines has been shown to depend on their morphology and consequently their flight performance, particularly their manoeuvrability. Principally, species with high wing loading and low aspect run a high risk of colliding with power lines. They are characterised by rapid flight and a combination of heavy body and small wings, which restricts swift reactions to unexpected obstacles (Bevanger 1998). When the number of reported collision victims is considered relative to the abundance and population size of the species concerned, some Galliformes, Gruiformes, Pelecaniformes and Ciconiiformes seem to be affected in disproportionately high numbers (Bevanger 1998). A study on power line collisions in west-central Spain indicated that birds with a high body mass and relatively short wings and tails, described as "poor fliers," such as Great Bustard and Little Bustard Tetrax tetrax, are at greatest risk of collision (Janss 2000).

Collisions with power lines have been frequently reported for Great Bustards (Cramp and Simmons 1980, Cardoso 1985, Janss and Ferrer 1998, 2000, Alonso et al. 2005, Martín et al. 2007). The species is considered globally threatened (Birdlife International 2008) and classified as "Vulnerable" in the IUCN Red List (IUCN 2009). Land privatisation and subsequent land-use change in Eastern Europe, Russia and Central Asia might lead to a rapid population reduction over the next three generations (Birdlife International 2009), although a recent estimate of the global status of the species indicates that total numbers have not decreased during the last decade, in contrast to the declining trend currently assumed (Palacín and Alonso 2008). Bevanger (1998) emphasised that an alarmingly large number of species with endangered and vulnerable status are among the victims of reported bird-strikes on power lines, but there are insufficient data at present for judging the significance of this mortality at the population level.

Apart from illegal hunting, collisions with overhead power lines are currently the most significant mortality factor for Great Bustards in several countries (e.g. Martín et al. 2007). In Portugal, a mean annual collision rate of almost $7 \%$ (92 individuals) of the national Great Bustard population has been reported (Infante et al. 2005). A study on radio-tagged Great Bustards in Spain documented mortality caused by collision with power lines of $54.5 \%$ for birds during the second year of life (Martín et al. 2007).

The present study investigated effects of power lines on the flight behaviour of Great Bustards in eastern Austria, western Hungary and western Slovakia - home to more than $95 \%$ of the total West-Pannonian population (Raab 2009, Raab et al. in prep.). Although the West-Pannonian population of the Great Bustard recovered after a serious decline in the last century from about 130 individuals in 1995 to more than 370 birds in 2009 (Raab et al. 2010), power lines still represent a serious threat as demonstrated by 33 deadly incidents due to collisions in the period June 2001-May 2009 (Raab 2009, Raab et al. 2010). In particular, we investigated whether the presence of power lines affects the flight direction at take-off and up to what distance power lines have an impact on flight paths. 


\section{Methods}

\section{Study areas}

The study was conducted in one Important Bird Area ("Rauchenwarther Platte") and four Special Protection Areas (SPA "Westliches Weinviertel", SPA "Sandboden und Praterterrasse", SPA "Waasen-Hanság" and SPA "Parndorfer Platte-Heideboden" around the Austrian-HungarianSlovakian border) in eastern Austria; one area across the Slovakian and Hungarian border (SPA "Sysl'ovské polia" and the northern part of the SPA "Mosoni-sík"), and one in the Hungarian Moson Plain (the southern part of the SPA "Mosoni-sík") (Figure 1), covering a total area of c.45,00o ha. The study areas are mainly flat or gently undulating agricultural areas dominated by cereal fields and comprising a varying extent of fallow fields, and are largely free of vertical structures like trees or hedges; a landscape structure preferred by Great Bustards (Collar 1996, Osborne et al. 2001). All study areas are crossed by power lines.

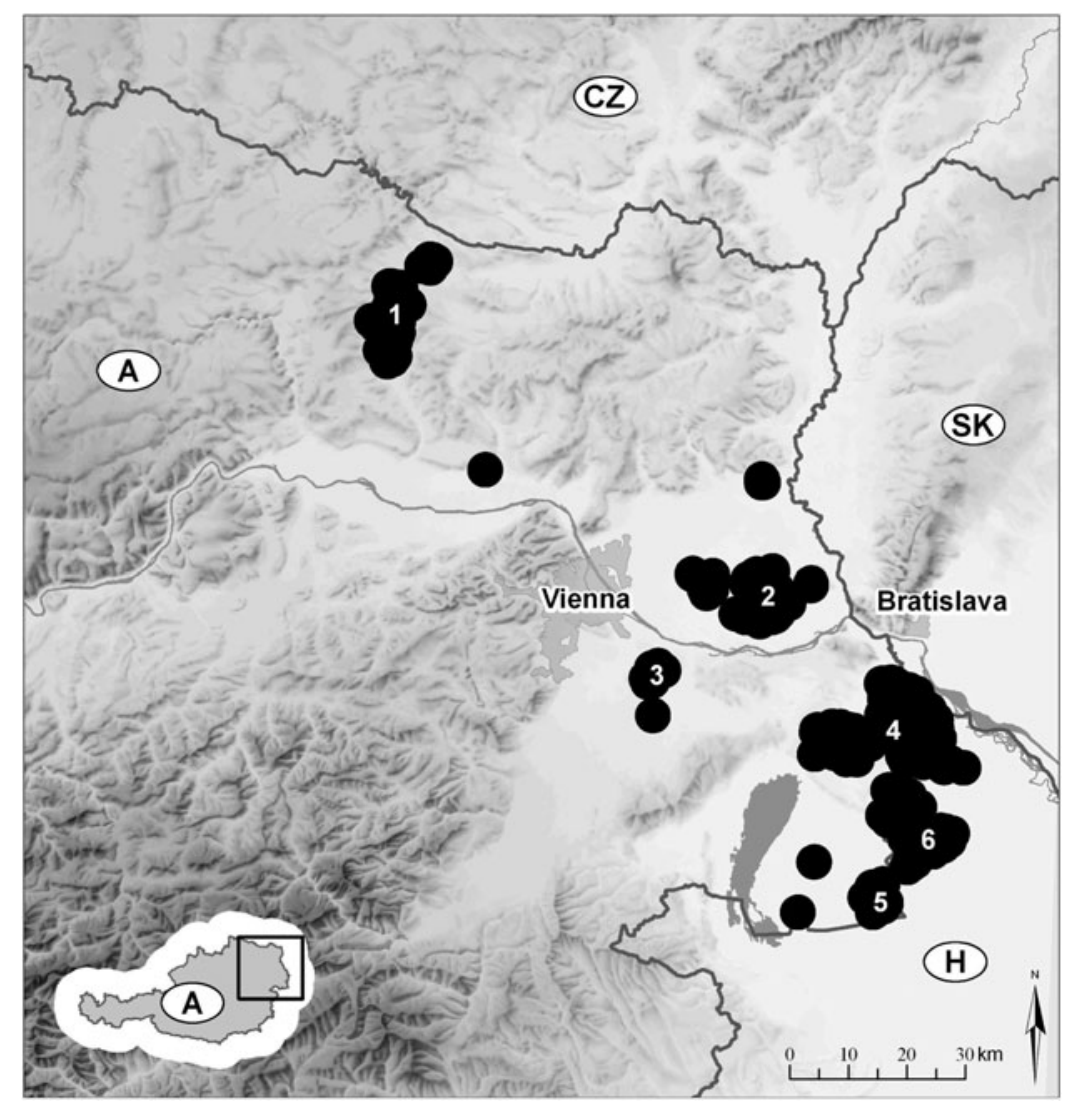

Figure 1. Locations of the West-Pannonian population of Great Bustard in the period from 2002 to 2008 with observed flight movements; locations in and around SPA "Westliches Weinviertel" (I), SPA "Sandboden und Praterterrasse" (2), "Rauchenwarther Platte" (3), SPA "Parndorfer PlatteHeideboden" (in Austria), SPA "Sysl'ovské polia" (in Slovakia) and the northern part of the SPA "Mosoni-sík" (in Hungary) (4), SPA "Waasen-Hanság" (5) the southern part of the SPA "Mosonisík" (in Hungary) (6) and additional locations with observations (black circles $=3 \mathrm{~km}$ buffer zones around Great Bustard individuals observed during take-off). 


\section{Flight directions of Great Bustards after take-off}

Observations on the flight behaviour of Great Bustards were made during surveys conducted in the years 2002-2008. Flight movements of Great Bustards after take-off were recorded in the field by drawing on detailed maps (scale 1:12,500). Later, all aerial movements were digitised in a Geographical Information System (software package ArcMap 9.1, ESRI). Flight directions of Great Bustards were taken as the bearing of a straight line drawn from the birdś take-off sites to their position after the first $100 \mathrm{~m}$ flown. When more than one individual synchronously took off, the mean flight direction of the flock was considered, which in the vast majority of cases was identical for all birds within the flock, 1oo $\mathrm{m}$ after take-off. In total, 2,832 such observations were available for analysis (2,604 observations by R. Raab, P. Spakovszky and E. Julius, plus 228 others). The majority of observations are from areas 4 (1,741 observations) and 1 (614). Smaller numbers of observations are available from the other study areas (area 2: 256; area 6: 195; area 5: 16; area 3: 9, between area 1 and 3: 1). The number of observations from individual years increased from 199 in 2002 to 752 in 2008. Observations cover all months of the year ranging from a monthly total of 153 in December to 390 in April. Observed flight movements of Great Bustards and exact locations of all power lines were available as shape files for further data processing with ArcView 3.3.

The following key variables were quantified for all observations: (I) shortest distance between a Great Bustard's take-off site and nearest power line; (2) the angle between flight direction and the perpendicular on the nearest power line, ranging from $0^{\circ}$ (bird flies directly towards nearest power line) to $180^{\circ}$ (bird flies away from nearest power line).

Landscape elements such as roads and tracks frequently used by cars, agricultural vehicles or walkers may be another source of disturbance causing avoidance by Great Bustards and therefore affecting the birds flight direction after take-off. Therefore, we additionally digitised roads and tracks with ArcMap 9.1.

\section{Data analysis}

To test for effects of the distance between take-off site and nearest power line on flight direction preferences of Great Bustards, we applied circular statistics calculated with the program Oriana version 3.01 (Kovach Computing Services). Observations were grouped according to the distance from the next power line in $200 \mathrm{~m}$ belts. For flight movements of each group of birds, we calculated the mean vector, which has two properties: its direction (the mean angle, $\mu$ ) and its length $r$. The length $r$ ranges from o to 1 ; larger $r$ values indicate that observations are clustered more closely around the mean. The circular standard deviations were calculated as $S=(-2 \ln (r))^{1 / 2}$ and subsequently were converted to degrees by multiplying by $180 / \pi$.

Rayleigh's Uniformity Test (Fisher 1993) was used to calculate the probability that flight directions were distributed in a uniform manner. Rayleigh $Z$ values quantify the likelihood of flight directions being uniformly distributed with larger $Z$ values indicating greater concentration of flight directions around the mean. A probability less than a chosen significance level (in this study 0.01) indicates that the flight directions of Great Bustards are not distributed uniformly, and that there is evidence for a preferred direction.

To rule out the possibility that road and tracks as a potential source of disturbance may bias our results, a Spearman rank correlation was applied to test if they are randomly distributed or associated with power lines. Therefore, we related the total length of roads and tracks to the total length of power lines measured for $500 \mathrm{~m} \times 500 \mathrm{~m}$ grids using ArcMap 9.1, only considering grids from which Bustard observations were available for analysis. Unfortunately, such data on the length of roads and tracks were only available for four of the larger study areas: "Sandboden und Praterterrasse" (2), "Waasen-Hanság" (5), "Westliches Weinviertel" (I) and "Parndorfer Platte-Heideboden" (including areas in SK and HU)" (4) Figure 1. 


\section{Results}

Considering all observations of flight directions after take-off, the mean flight direction of Great Bustards deviated significantly from a random distribution in all 200-m distance belts up to $800 \mathrm{~m}$ from the nearest power line (Figures 2-3). The mean flight direction angles (between $170^{\circ}$ and $198^{\circ}$ ) clearly indicate that flight routes after take-off point away from power lines. At larger distances there is increasingly less evidence for a preferred flight direction (Figure 2). However, flight directions of bustards still deviated from a random distribution in two $200 \mathrm{~m}$ distance bands

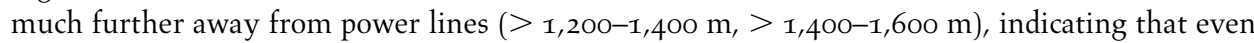
at larger distances flight directions might still be affected by such artificial landscape elements (Figure 2).

The decreasing influence of power lines on flight directions of Great Bustards with increasing distance of take-off site from nearest power line is also indicated by mean vector lengths $(r)$ of flight paths and circular standard deviations $(S)$ calculated for all defined 200-m distance belts: With increasing distance to nearest power lines, $r$ values decrease significantly (Figure $4 a$ ), while circular standard deviations increase significantly (Figure 4 b).

No relationship between total length of roads and tracks and power line length of $500 \mathrm{~m} \times 500$ $\mathrm{m}$ grids was found at "Sandboden und Praterterrasse" (Spearman rank correlation; $r_{\mathrm{s}}=-0.06$, $n=240$ grids, $P=0.321)$ and "Waasen-Hanság" $\left(r_{\mathrm{s}}=0.12, n=70, P=0.312\right)$, a weak negative relationship was indicated for "Westliches Weinviertel" $\left(r_{\mathrm{s}}=-0.17, n=196, P=0.018\right)$ and a strong positive relationship exists in study area "Parndorfer Platte-Heideboden" $\left(r_{\mathrm{s}}=0.22\right.$, $n=514, P<0.001$ ). Due to these differences in the association of power lines with another

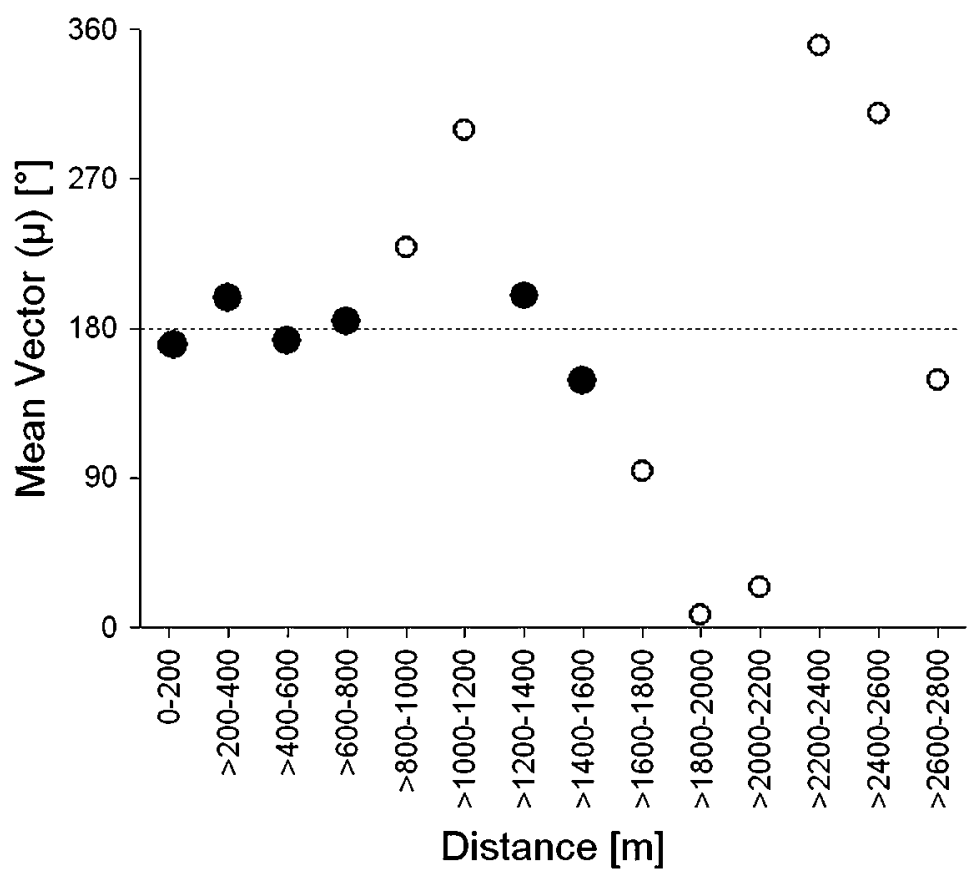

Figure 2. Mean flight directions of Great Bustards after take-off at different distances to power lines. Flight directions described by an angle of $180^{\circ}$ point directly away from power lines. Significant deviations from a random distribution of flight directions are indicated by filled circles (at a level of $P<$ o.o1; Rayleigh's Uniformity Test). 

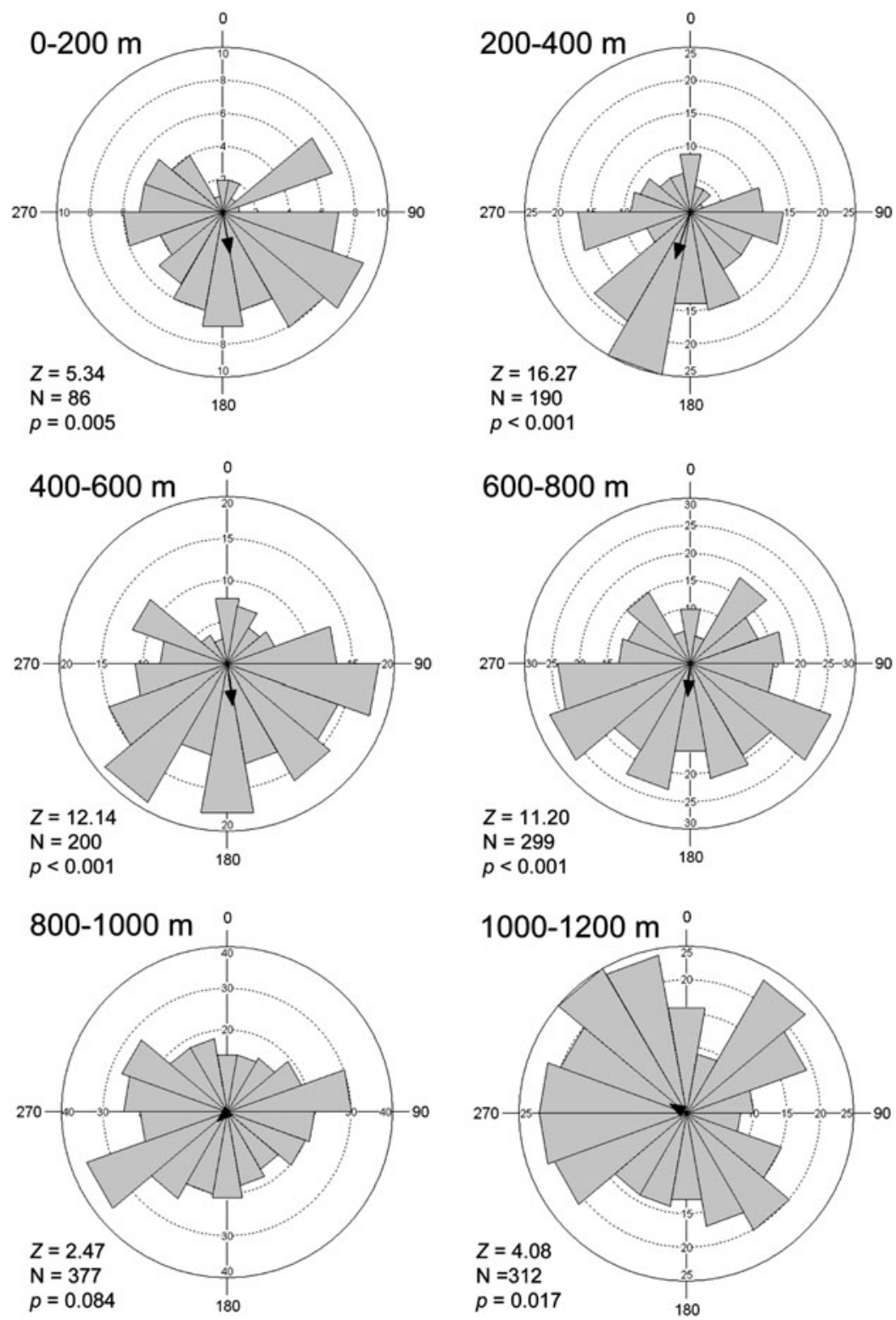

Figure 3. Flight directions of Great Bustards after takeoff in different $200 \mathrm{~m}$ distance belts to power lines. Mean flight directions are indicated by arrows. Additionally, results of Rayleigh's Uniformity Tests are provided. $n=$ number of observed bustards and flocks of bustards, respectively for which flight directions.

potential source of disturbance (roads and tracks) between study areas, all analyses testing for effects of power lines on flight direction were also calculated separately for three of these study areas, for which enough observations on flight directions after take-off were available: "Parndorfer Platte-Heideboden" ( $n=1,741$ observations), "Westliches Weinviertel" $\left(n=61_{4}\right)$ and "Sandboden und Praterterrasse" $(n=256)$. While for the first study area data on flight directions 

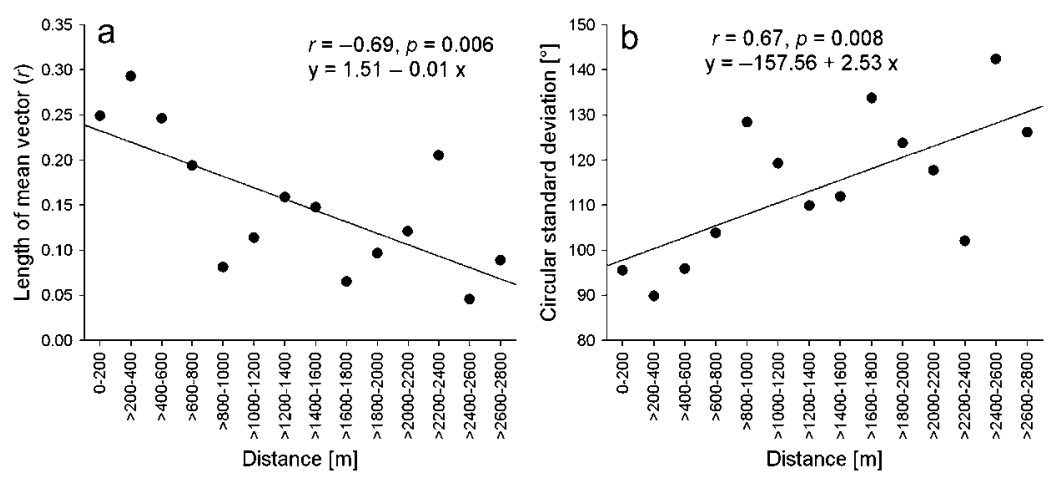

Figure 4. Effects of distance to power lines on length $r$ of mean vectors (a) and circular standard deviations (b) of flight directions of Bustards after takeoff. In addition, results of linear regressions and regression functions are provided.

after take-off were again pooled for $200 \mathrm{~m}$ belts, for the other two, data had to be pooled for $400 \mathrm{~m}$ belts to achieve sample sizes large enough for conducting reliable analyses.

The separate analyses of bustard flight directions for these three study areas indicate very similar results independent if a positive association between power lines and roads (study area "Parndorfer Platte-Heideboden"), a weak negative relationship ("Westliches Weinviertel") or no association ("Sandboden und Praterterrasse") existed. Mean direction angles of flight routes after take-off point away from power lines at distances up to $800 \mathrm{~m}$, in some cases up to $1200-$ $1600 \mathrm{~m}$ (Fig. 5). Furthermore, mean vector lengths $(r)$ of flight paths decrease with increasing distance to nearest power lines (Fig. 6); circular standard deviations increase at all three study areas (Fig. 7). However, not all regression analysis achieved a significant level although the respective trends are obvious for all three study areas (compare Figs. 6-7).

\section{Discussion}

Despite the limitations of most studies on bird collisions with artificial structures such as power lines, it is apparent that bird strikes are a significant cause of mortality in larger bird species (Brown and Drewien 1992, Drewitt and Langston 2008), besides electrocution (Rubolini et al. 2001). Both may potentially have severe effects on bird populations (e.g. Crivelli et al. 1988, Rubolini et al. 2001). Several measures such as marking of power lines have been suggested that can successfully reduce the collision and/or electrocution risk of large birds (Brown and Drewien 1995, Bevanger and Brøseth 2001, IEEE Task Force on Reducing Bird Related Power Outages 2004). However, a study on the collision risk of Great Bustards in Spain did not find a decrease in casualties related to the marking of power lines (Janss and Ferrer 1998).

Birds can reduce the collision risk by adapting their flight behaviour as demonstrated by our study that shows a strong effect of power lines on flight behaviour of Great Bustards. At least up to a distance of $800 \mathrm{~m}$, mean flight directions after take-off pointed away from power lines. However, our results indicate that these artificial structures affect bustards' flight behaviour even at larger spatial scales up to a distance of $1,600 \mathrm{~m}$. Changes in flight behaviour of larger bird species in response to man-made structures have been documented before (e.g. Shimada 2001). Large interspecific variations in sensitivity to power lines have been observed with Great Bustards preferring to avoid crossing power lines more frequently than other birds (such as cranes) (Janss and Ferrer 2000). It has been shown as well that soaring birds during migration can detect the presence of wind turbines and change their flight direction when flying in close proximity, which most likely explained the low number of dead birds found in the studied wind farm area (de Lucas 

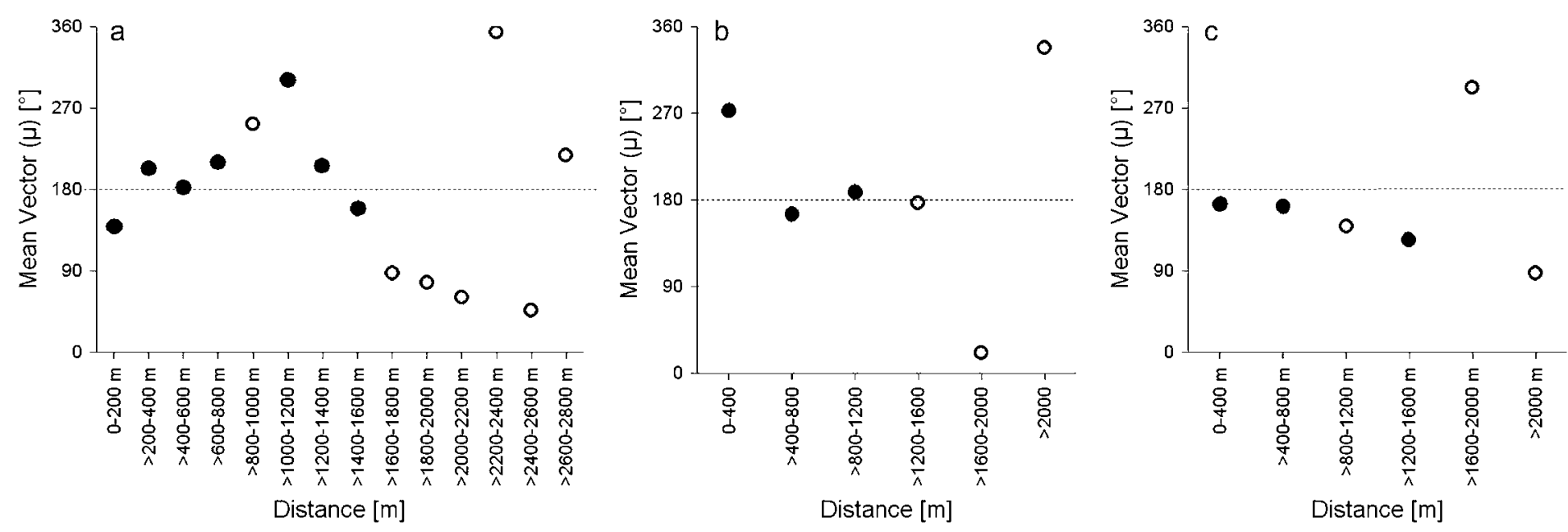

Figure 5. Mean flight directions of Great Bustards after takeoff at different distances to power lines at three different study areas: "Parndorfer Platte-Heideboden" (a), "Westliches Weinviertel" (b) and "Sandboden und Praterterrasse" (c). Flight directions described by an angle of $180^{\circ}$ point directly away from power lines. Significant deviations from a random distribution of flight directions are indicated by filled circles (at a level of $P<0.01$; Rayleigh's Uniformity Test). 

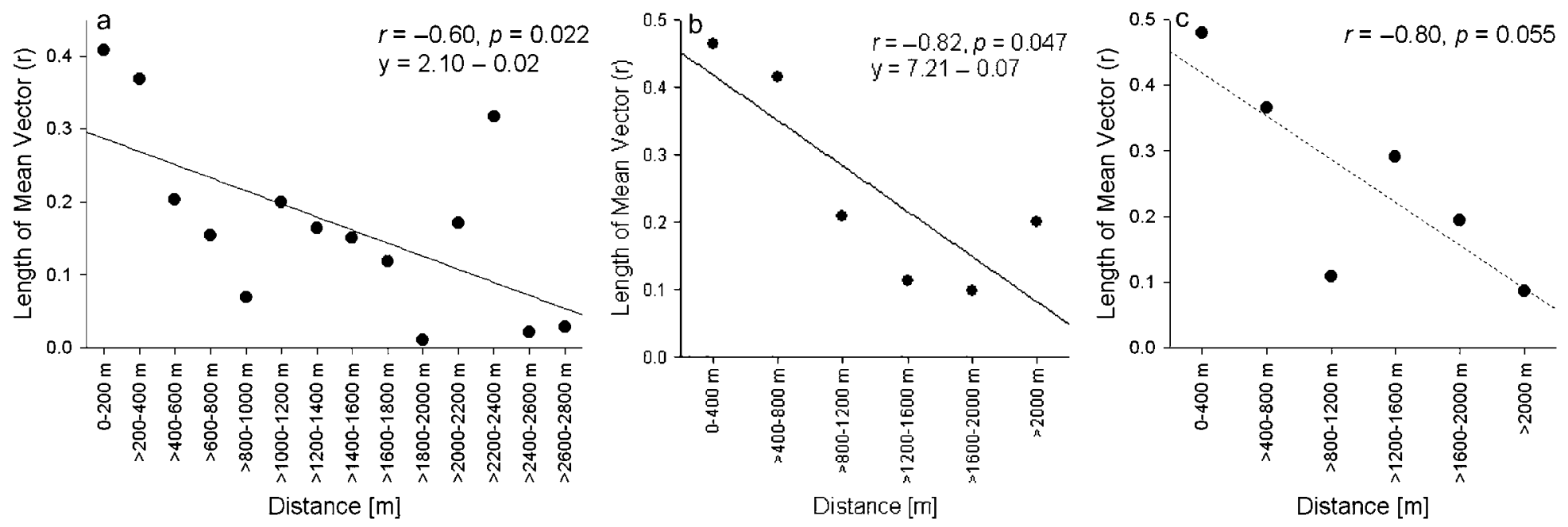

Figure 6. Effects of distance to power lines on length $r$ of mean vectors of flight directions of Bustards after takeoff at three different study areas: "Parndorfer Platte-Heideboden" (a), "Westliches Weinviertel" (b) and "Sandboden und Praterterrasse" (c). In addition, results of linear regressions and regression functions (only for significant regressions) are provided. A trend which did not achieve a significant level is indicated by broken regression lines. 

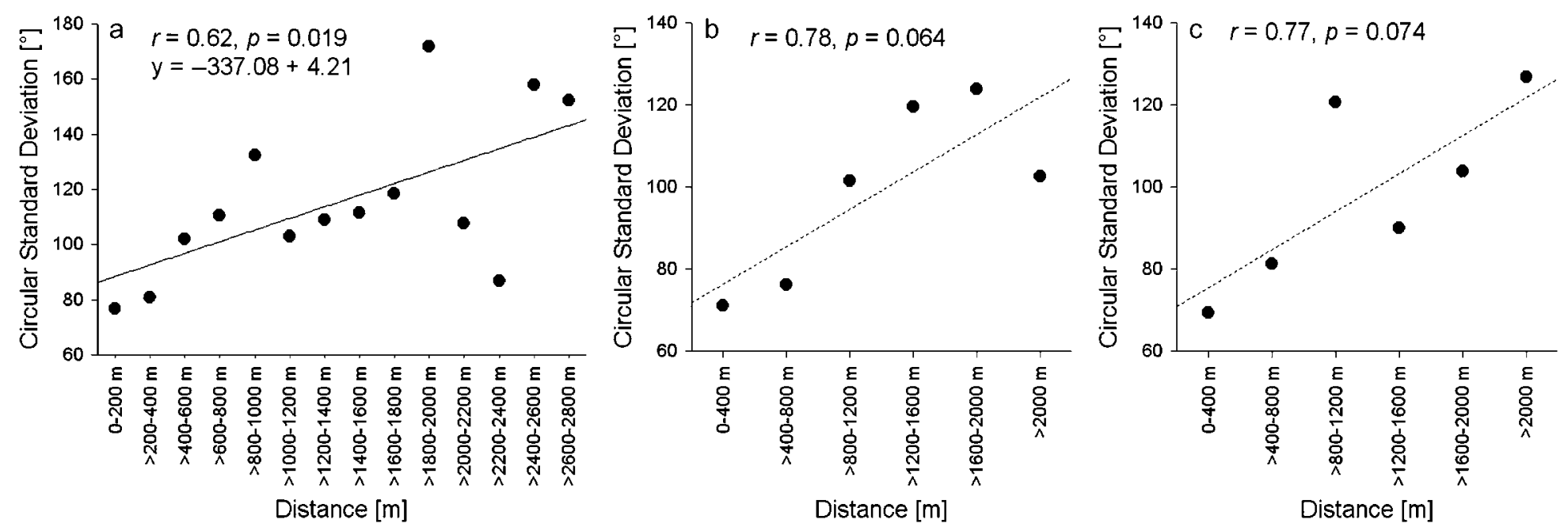

Figure 7. Effects of distance to power lines on circular standard deviations of flight directions of Bustards after takeoff at three different study areas: "Parndorfer Platte-Heideboden" (a), "Westliches Weinviertel" (b) and "Sandboden und Praterterrasse" (c). In addition, results of linear regressions and regression functions (only for significant regressions) are provided. A trend which did not achieve a significant level is indicated by broken regression lines. 
et al. 2004). However, the likelihood of collision mortality can differ depending on the location of man-made structures. A greater risk of collision was observed when such artificial structures were placed on or near areas regularly used by large numbers of feeding, breeding, or roosting birds, or on local flight paths, such as those between foraging and nesting or roosting areas (Faanes 1987, Everaert and Stienen 2007).

Our study demonstrates that beside the collision risk, power lines have a high potential to result in habitat loss in a similar way to wind turbines which can reduce the habitat for foraging and breeding waterfowl (Osborn et al. 1998, Larsen and Madsen 2000, Guillemette and Larsen 2002).

Our finding has important implications for the conservation of the relatively small populations of Great Bustards at the western margin of the Pannonian distribution range of the species. Such small marginal populations are particularly at risk of local extinction as documented for Spanish Great Bustards (Alonso and Alonso 1996, Lane and Alonso 2001). Although the adaptation of flight routes after take-off in response to nearby power lines may reduce the risk of collision, such man-made structures most likely have severe consequences for the spatial movements of Great Bustards within the entire landscape and particularly between potentially suitable breeding and foraging habitats. Furthermore, there are likely significant effects on the time and energy budget of birds moving between different locations to visit feeding, breeding and, in the case of the Great Bustard, courtship sites. Therefore spatial movements of bustard populations have to be carefully monitored and considered when planning new power lines around or between breeding and wintering grounds of this highly endangered species. Marking is a compromise to reduce the collision risk, but marked power lines influence flight directions more strongly than unmarked power lines (Alonso et al. 1994). We therefore recommend "undergrounding" of cables instead of marking power lines, because this should eliminate every negative effect of the power line on birds.

\section{Acknowledgements}

We would like to give our special thanks to more than 700 people involved in conservation projects for the West-Pannonian Great Bustard population. The three LIFE Projects "Crossborder Protection of the Great Bustard in Austria" (LIFEo5 NAT/A/oooo77), www.grosstrappe.at; "Conservation of Otis tarda in Hungary" (LIFEo4 NAT/HU/ooo1o9), www.tuzok.hu; "Conservation of Otis tarda in Slovakia" (LIFEo5 NAT/SK/ooo115), www.dropy.sk, are supported by the EU, many project partners and co-financiers. Additional EU co-financed projects are supported by the Austrian Federal Ministry for Agriculture, Forestry, Environment and Water management (BMLFUW), the regional governments of Lower Austria and Burgenland. Without this support the time-intensive work for the conservation of the entire West-Pannonian Great Bustard population during recent years would not have been possible. We are grateful to Björn Beckmann for proofreading a first draft of the manuscript. Rainer Raab would like to extend his special thanks to his PhD supervisor Hans Winkler. We also like to thank Olivier Combreau for helpful comments which significantly improved the manuscript.

\section{References}

Alonso, J. C., Martín, C. A., Palacín, C., Martín, B. and Magaña, M. (2005) The Great Bustard Otis tarda in Andalusia, southern Spain: Status, distribution and trends. Ardeola 52: 67-78.

Alonso, J. C. and Alonso, J. A. (1996) The Great Bustard Otis tarda in Spain: present status, recent trends and an evaluation of earlier censuses. Biol. Conserv. 77: 79-86.

Alonso, J. C., Alonso, J. A. and MuñozPulido, R. (1994) Mitigation of bird collisions with transmission lines through groundwire marking. Biol. Conserv. 67: 129-134. 
Barrios, L. and Rodríguez, A. (2004) Behavioural and environmental correlates of soaring-bird mortality at on-shore wind turbines. J. Appl. Ecol. 41: 72-81.

Bevanger, K. (1995) Estimates and population consequences of tetraonid mortality caused by collisions with high tension power lines in Norway. J. Appl. Ecol. 32: 745-753.

Bevanger, K. (1998) Biological and conservation aspects of bird mortality caused by electricity power lines: a review. Biol. Conserv. 86: 67-76.

Bevanger, K. and Brøseth, H. (2001) Bird collisions with power lines - an experiment with ptarmigan (Lagopus spp.). Biol. Conserv. 99: 341-346.

Bevanger, K. and Brøseth, H. (2004) Impact of power lines on bird mortality in a subalpine area. Anim. Biodiv. Conserv. 27: 67-77.

BirdLife International (2008) Threatened birds of the world 2008: CD-Rom. Cambridge, UK: BirdLife International.

Birdlife International (2009) Species factsheet: Otis tarda. http://www.birdlife.org. [Accessed: 12 June 2009].

Brown, W. M. and Drewien, R. C. (1992) Marking power lines to reduce avian collision mortality in the San Luis Valley, Colorado. Proc. North Am. Crane Workshop 6: 177 .

Brown, W. M. and Drewien, R. C. (1995) Evaluation of two power line markers to reduce crane and waterfowl collision mortality. Wildlife Soc. Bull. 23: 217-227.

Burger, J. (1998) Effects of motorboats and personal watercraft on flight behavior over a colony of common terns. Condor 100: 528-534.

Cardoso, J. J. V. (1985) A project to halt the decline of the great bustard on the Extremadura plains. Bustard Studies 2: 73-74.

Collar, N. J. (1996) Family Otididae (Bustards). Pp. 240-273 in J. del Hoyo, A. Elliott and J. Sargatal, eds. Handbook of the birds of the world. Vol. 3. Hoatzin to Auks. Barcelona: Lynx Edicions.

Cramp, S. and Simmons, K. K. L., eds. (1980) $A$ handbook of the birds of Europe, the Middle East and North Africa: The birds of the Western Palearctic. Vol. II, Hawks to Bustards. Oxford: Oxford University Press.
Crivelli, A. J., Jerrentrup, H. and Mitchev, T. (1988) Electric power lines: a cause of mortality in Pelecanus crispus Bruch, a world endangered bird species. Colonial Waterbirds 11: 301-305.

de Lucas, M., Janss, G. F. E. and Ferrer, M. (2004) The effects of a wind farm on birds in a migration point: the Strait of Gibraltar. Biodiv. Conserv. 13: 395-407.

Drewitt, A. L. and Langston, R. H. W. (2008) Collision effects of wind-power generators and other obstacles on birds. Ann. New York Acad. Sci. 1134: 233-266.

Everaert, J. and Stienen, E. W. M. (2007) Impact of wind turbines on birds in Zeebrugge (Belgium): significant effect on breeding tern colony due to collisions. Biodiv. Conserv. 16: 3345-3359.

Faanes, C. A. (1987) Bird behaviour and mortality in relation to powerlines in prairie habitats. Washington DC: US Department of the Interior, Fish and Wildlife Service.

Fisher, N. I. (1993) Statistical analysis of circular data. Cambridge, UK: Cambridge University Press.

Guillemette, M. and Larsen, J. K. (2002) Postdevelopment experiments to detect anthropogenic disturbances: the case of sea ducks and wind parks. Ecol. Applic. 12: 868-877.

Hanowski, J. M. and Hawrot, R. Y. (2000) Avian issues in the development of wind energy in Western Minnesota. Pp. 8o-87 in PNAWPPM-III (ed). Proceedings of $\mathrm{Na}$ tional Avian - Wind Power Planning Meeting III, San Diego, California, May 1998. King City: LGL Ltd.

IEEE Task Force on Reducing Bird Related Power Outages (2004) Preventive measures to reduce bird-related power outages Part I: Electrocution and collision. IEEE Trans. on Power Delivery 19: 1843-1847.

Infante, S., Neves, J., Ministro, J. and Brandão, R. (2005) Estudo sobre o Impacto das Linhas Eléctricas de Média e Alta Tensão na Avifauna em Portugal. Quercus Associação Nacional de Conservação da Natureza e SPEA Sociedade Portuguesa para o Estudo das Aves, Castelo Branco. http://portal. icnb.pt/NR/rdonlyres/Ao4AE662-7439-4FF6AoD4-Eo162DoA9245/o/ 
PORImpacto_LinhasElectricas_2005.pdf. [Accessed: 30 October 2009].

IUCN (2009) IUCN Red List of threatened species. Version 2009.1. http://www. iucnredlist.org. [Accessed: 10 June 2009].

Janss, G. F. E. (2000) Avian mortality from power lines: a morphologic approach of a species-specific mortality. Biol. Conserv. 95: 353-359.

Janss, G. F. E. and Ferrer, M. (1998) Rate of bird collision with power lines: effects of conductor-marking and static wire-marking. J. Field Ornithol. 69: 8-17.

Janss, G. F. E. and Ferrer, M. (2000) Common crane and great bustard collision with power lines: collision risk and risk exposure. Wildlife Soc. Bull. 28: 675-68o.

Jenkins, A. R., Smallie, J. J. and Diamond, M. (2010) Avian collisions with power lines: a global review of causes and mitigation with a South African perspective. Bird Conserv. Int. 20: $263-278$.

Lane, S. J. and Alonso, J. C. (2001) Status and extinction probabilities of great bustard (Otis tarda) leks in Andalucía, southern Spain. Biodivers. Conserv. 10: 893-910.

Larsen, J. K. and Madsen, J. (2000) Effects of wind turbines and other physical elements on field utilization by pink-footed geese (Anser brachyrhynchus): a landscape perspective. Landscape Ecol. 15: 755-764.

Martín, C. A., Alonso, J. A., Alonso, J. A., Palacín, C., Magaña, M. and Martín, B. (2007) Sex-biased juvenile survival in a bird with extreme size dimorphism, the great bustard Otis tarda. J. Avian Biol. 38: 335-346.

Nelson, H. K. and Curry, R. C. (1995) Assessing avian interactions with windplant development and operation. Trans. North Am. Wildlife Nat. Resources Conference 6o: 266-287.

Osborn, R. G., Dieter, C. D., Higgins, K. F. and Usgaard, R. E. (1998) Bird flight characteristics near wind turbines in Minnesota. Am. Midland Nat. 139: 20-38.
Osborne, P. E., Alonso, J. C. and Bryant, R. G. (2001) Modelling landscape-scale habitat use using GIS and remote sensing: a case study with Great Bustards. J. Appl. Ecol. 38 : 458-471.

Palacín, C. and Alonso, J. C. (2008) An updated estimate of the world status and population trends of the Great Bustard Otis tarda. Ardeola 55: 13-25.

PNAWPPM-III (2000) Proceedings of national avian - wind power planning meeting III, San Diego, California, May 1998. King City: LGL Ltd.

Raab, R. (2009) Cross-border conservation of the West-Pannonian Great Bustard population in Austria, Czech Republic, Hungary and Slovakia and conservation measures in agricultural habitats in Austria. Pp. 31-36 in C. Attie and T. Micol, eds. Protection of bustards in Europe: reinforcement or reintroduction: which is the best conservation strategy? LPO and BirdLife International.

Raab, R., Kollar, H. P., Winkler, H., Faragó, S., Spakovszky, P., Chavko, J., Maderič, B., Škorpíková, V., Patak, E., Wurm, H., Julius, E., Raab, S. and Schütz, C. (2010) Die Bestandsentwicklung der westpannonischen Population der Großtrappe, Otis tarda Linnaeus 1758, von 1900 bis zum Winter 2008/2009. Egretta 51: 74-99.

Rollan, A., Real, J., Bosch, R., Tintó, A. and Hernández-Matías (2010) Modelling the risk of collision with power lines in Bonelli's Eagle Hieraaetus fasciatus and its conservation implications. Bird Conserv. Int. 20: 279-294.

Rubolini, D., Bassi, E., Bogliani, G., Galeotti, P. and Garavaglia, R. (2001) Eagle Owl Bubo bubo and power line interactions in the Italian Alps. Bird Conserv. Int. 11: 319-324.

Shimada, T. (2001) Choice of daily flight routes of Greater White-fronted Geese: Effects of power lines. Internat. J. Waterbird Biol. 24: 425-429.

RAINER RAAB*, EIKE JULIUS, CLAUDIA SCHÜTZ

Technisches Büro für Biologie, Quadenstraße 13, A-2232 Deutsch-Wagram, Austria. 


\section{PÉTER SPAKOVSZKY}

University of West Hungary, Institute of Wildlife Management and Vertebrate Zoology, H9400 Sopron, Ady E. u. 5. and Technisches Büro für Biologie, Quadenstraße 13, A-2232 Deutsch-Wagram, Austria.

\section{CHRISTIAN H. SCHULZE}

Department of Animal Biodiversity, University of Vienna, Rennweg 14, A-1030 Vienna, Austria.

*Author for correspondence; e-mail: rainer.raab@gmx.at

Received 30 November 2009; revision accepted 7 July 2010;

Published online 11 August 2010 